\title{
DAMPAK BENCANA BANJIR PESISIR DAN ADAPTASI MASYARAKAT TERHADAPNYA DI KABUPATEN PEKALONGAN
}

\author{
Muh Aris Marfai ${ }^{1,2}$, Ahmad Cahyadi ${ }^{1}$, Achmad Arief Kasbullah¹, \\ Luthfi Annur Hudaya², Dela Risnain Tarigan², \\ ${ }^{1} J u r u s a n$ Geografi Lingkungan, Fakultas Geografi,Universitas Gadjah Mada \\ ${ }^{2}$ Prodi IImu Lingkungan Sekolah Pascasarjana Universitas Gadjah Mada \\ Email: arismarfai@yahoo.com, ahmadcahyadi@geo.ugm.ac.id
}

Penelitian ini bertujuan untuk mengetahui dampak banjir pesisir (rob) di Kabupaten Pekalongan serta bentuk-bentuk adaptasi masyarakat terhadap bencana ini di Kabupaten Pekalongan. Penelitian ini dilakukan dengan survei lapangan dan indepth interview terkait dengan dampak banjir rob dan pola adaptasi masyarakat terhadapnya. Hasil penelitian menunjukkan bahwa banjir rob di Kabupaten Pekalongan telah menyebabkan terjadinya kerusakan rumah, infrastruktur jalan, fasilitas umum seperti sekolah dan layanan kesehatan, sanitasi, lahan pekarangan, tegalan, persawahan dan lahan tambak. Adaptasi masyarakat terhadap banjir rob di Kabupaten Pekalongan diantaranya meninggikan bangunan rumah, meninggikan jalan, meninggikan bedengan tambak dengan jaring, serta pemanfaatan varietas padi yang tahan dengan salinitas yang tinggi.

Kata Kunci: Dampak, Adaptasi, Banjir Pesisir, Kabupaten Pekalongan

\section{Pendahuluan}

Marfai dan King (2008a) menyebutkan bahwa wilayah kepesisiran merupakan lingkungan yang sangat dinamis dengan berbagai penggunaan lahan yang sangat kompleks. Hal ini karena keunikan ekosistem yang terbentuk pada pertemuan ekosistem darat dan laut. Selain itu, kondisi ini dipicu oleh sumberdaya alam yang melimpah di kawasan tersebut, termasuk di dalamnya terkait dengan akses yang baik untuk mendukung aktivitas perindustrian dan distribusi barang.

Indonesia merupakan negara dengan wilayah kepesisiran yang luas karena memiliki garis pantai terpanjang kedua di dunia. Selain berartim bahwa potensi sumberdaya alam yang dimiliki melimpah, hal ini juga berarti bahwa banyak wilayah di Indonesia yang memiliki kerawanan bencana yang tinggi. Marfai dan King (2008b), Sartohadi dkk. (2009), Mardiatno dkk. (2009), dan Marfai dkk. (2009) mengungkapkan bahwa wilayah kepesisiran Indonesia merupakan wilayah yang sangat rawan untuk terkena bencana.

Banjir rob (banjir genangan) merupakan salah satu bencana yang mengancam wilayah kepesisiran di Indonesia (Marfai dan King, 2008c). Kenaikan muka air laut yang terus terjadi dapat menyebabkan bencana ini memiliki dampak yang semakin parah pada masa mendatang. Hal ini dikuatkan oleh pendapat Cabanes dkk. (2001) serta Cazenave dan Nerem (2004) yang mengungkapkan bahwa hasil pemantauan secara rutin melalui satelit, 
fakta memperlihatkan bahwa dalam kurun waktu 50 tahun, 27\% lapisan es di kutub utara telah mencair. Oleh karenanya, sangat tepat apabila Sutrisno dkk. (2005) mengungkapkan bahwa pembangunan wilayah kepesisira di masa mendatang haruslah memperhatikan kerawanan banjir rob.

Nicholls dkk. (2000) menyebutkan bahwa banjir rob di wilayah kepesisran dapat menyebabkan beberapa gangguan yang meliputi:

1. gangguan terhadap fungsi kawasan pesisir dan kota pantai,

2. gangguan terhadap fungsi prasarana dan sarana seperti jaringan jalan, pelabuhan dan bandara

3. gangguan terhadap permukiman penduduk,

4. pengurangan produktivitas lahan pertanian, dan

5. peningkatan risiko wabah penyakit.

Wilayah Kepesisiran Kabupaten Pekalongan merupakan salah satu wilayah pesisir di Wilayah Kepesisiran Utara Pulau Jawa yang mengalami fenomena banjir pasang air laut. Fenomena banjir pasang air laut di Kabupaten Pekalongan saat ini terjadi makin parah, di mana beberapa desa sampai saat ini masih sering dilanda banjir rob. Media Indonesia versi Cetak pada Rabu, 03 November 2010 menyebutkan bahwa banjir pasang air laut ini juga melanda ratusan hektar lahan pertanian dan tambak yang ada di kawasan pesisir. Berdasarkan fakta tersebut maka penelitian ini bertujuan untuk (1) mengetahui dampak banjir rob di wilayah kepesisiran Kabupaten Pekalongan dan (2) mengetahui pola adaptasi yang dilakukan masyarakat untuk menghadapi banjir rob di Kabupaten Pekalongan.

\section{Metode Penelitian}

Metode dalam penelitian ini dibagi menjadi dua bagian, yaitu analisis dampak banjir rob terhadap dan analisis pola adaptasi masyarakat terhadap banjir rob. Kajian terkait dampak banjir rob terhadap wilayah kepesisiran Kabupaten Pekalongan dilakukan dengan pengamatan lapangan dan indepth interview dengan beberapa tokoh masyarakat di tiga kecamatan yang terletak di lokasi kajian. Ketiga kecamatan tersebut adalah Kecamatan Tirto, Kecamatan Wonokerto dan Kecamatan Siwalan. Jumlah informan adalah 10 orang untuk masing-masing kecamatan.

\section{Hasil dan Pembahasan}

\section{Dampak Terhadap Permukiman}

Banjir rob di Kabupaten Pekalongan telah menyebabkan terjadinya kerusakan dan semakin menurunnya kualitas kondisi rumah. Babarapa rumah di pesisir Kabupaten 
Pekalongan tergenang air secara permanen sehingga tidak dapat digunakan lagi dan kemudian ditinggalkan oleh pemiliknya pindah ke lokasi lain (Gambar 1.). Beberapa rumah yang lain masih dapat digunakan karena hanya tergenang ketika terjadi gelombang pasang, dan beberapa rumah yang lain dimodifikasi dengan beberapa upaya adaptasi agar tidak tergenang banjir rob.

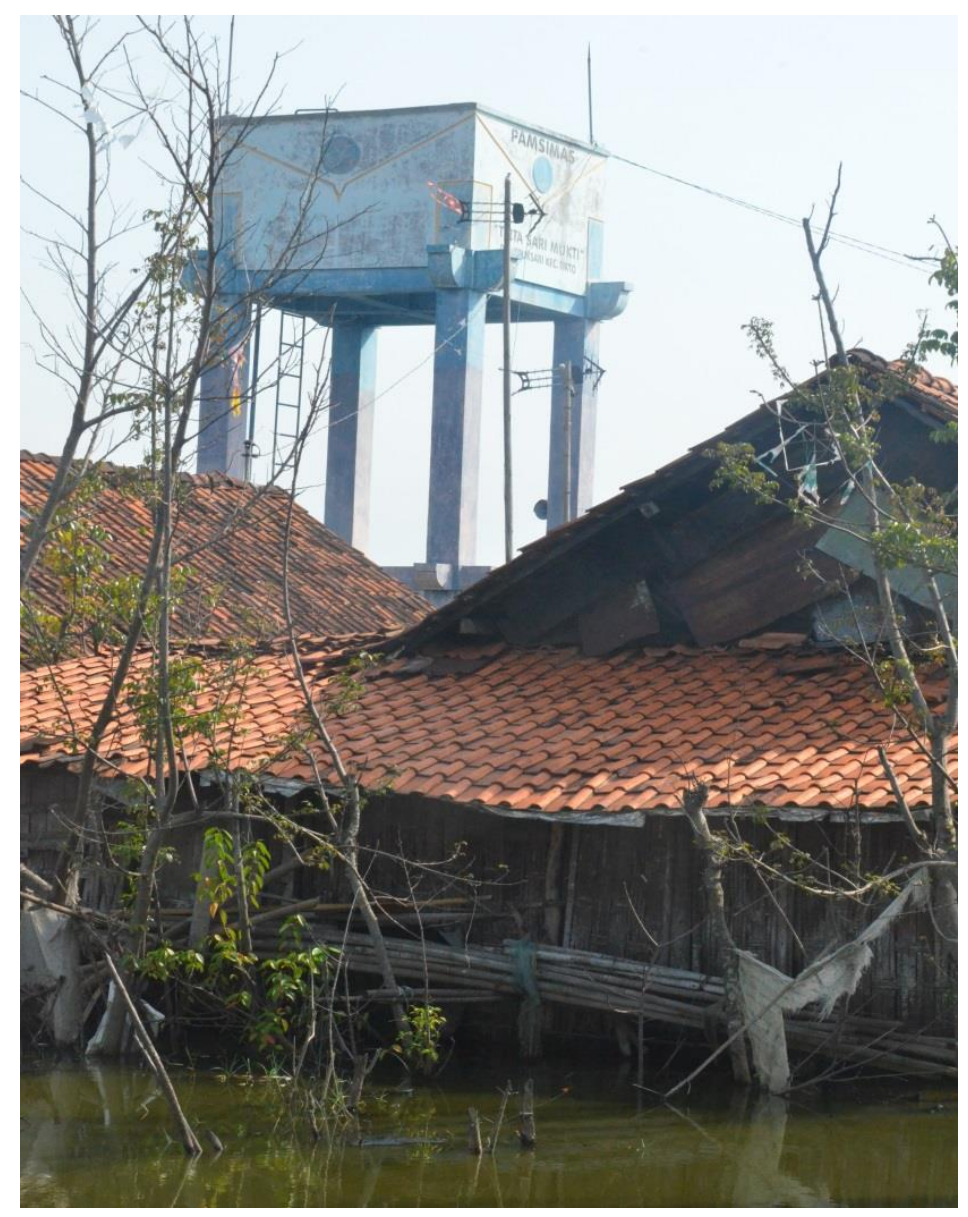

Gambar 1. Bangunan yang ditinggalkan karena ditinggalkan pemiliknya

(Dokumentasi Pribadi, 18 Juni 2014)

Beberapa upaya yang dilakukan masyarakat sebagai upaya untuk menggulangi banjir rob adalah dengan melakukan peninggian pada bagian pintu rumah (Gambar 2.), peninggian lantai rumah (Gambar 3.), pembuatan tanggul di depan rumah (4.) dan peninggian bangunan rumah. Beberapa warga yang memiliki kondisi ekonomi yang lebih baik memutuskan untuk pindah ke lokasi yang lebih baik kondisinya. Banyaknya warga yang tidak pindah disebabkan mata pencaharian mereka berada di lokasi kejadian yang sangat terkait dengan aktivitas nelayan tangkap dan nelayan tambak, sedangkan beberapa yang lain tidak memilih untuk pindah karena alasan ketiadaan biaya. 


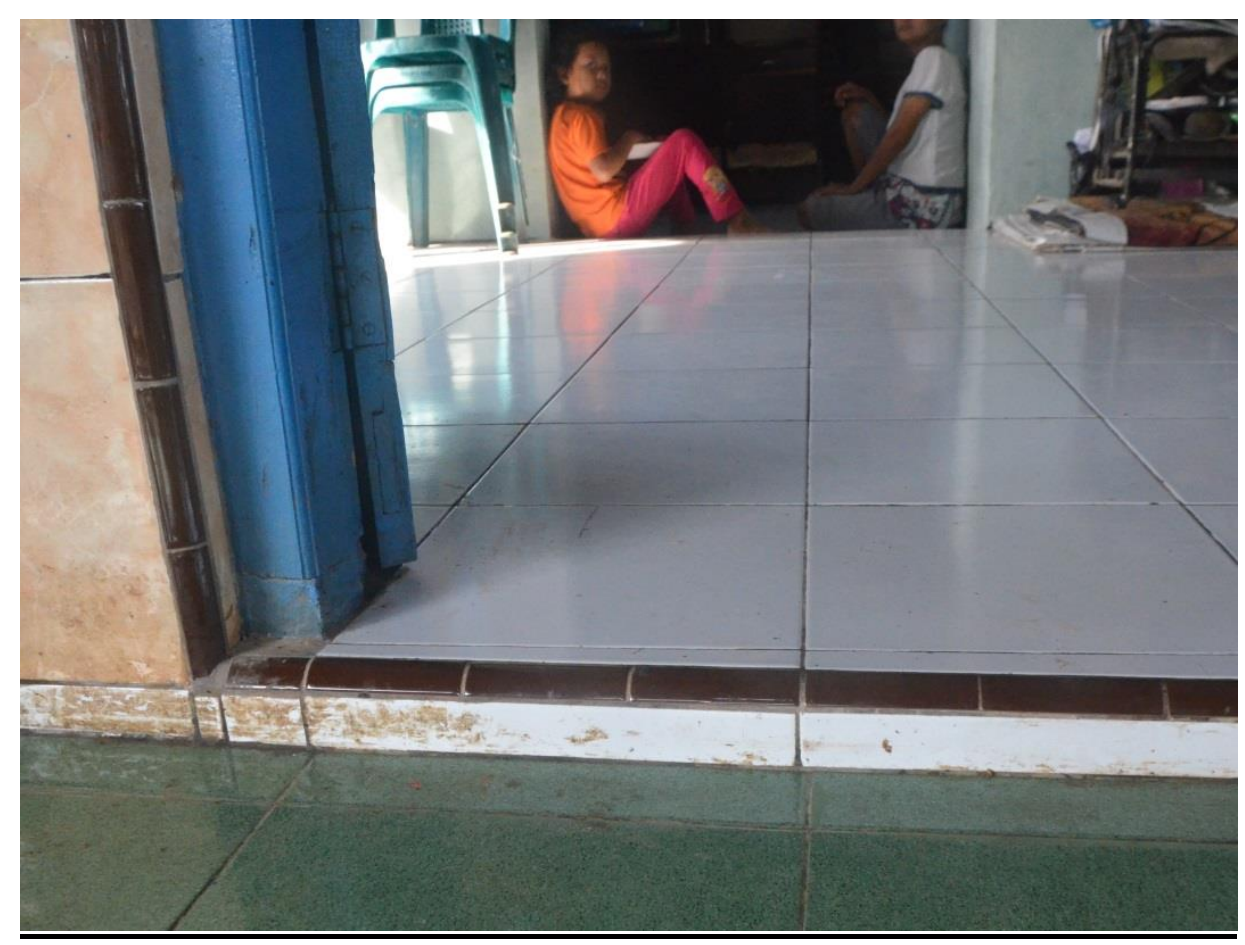

Gambar 2. Peninggian lantai di depan pintu sebagai bagian dari adaptasi terhadap banjir rob di Kabupaten Pekalongan (Dokumentasi Pribadi, 17 Juni 2014)

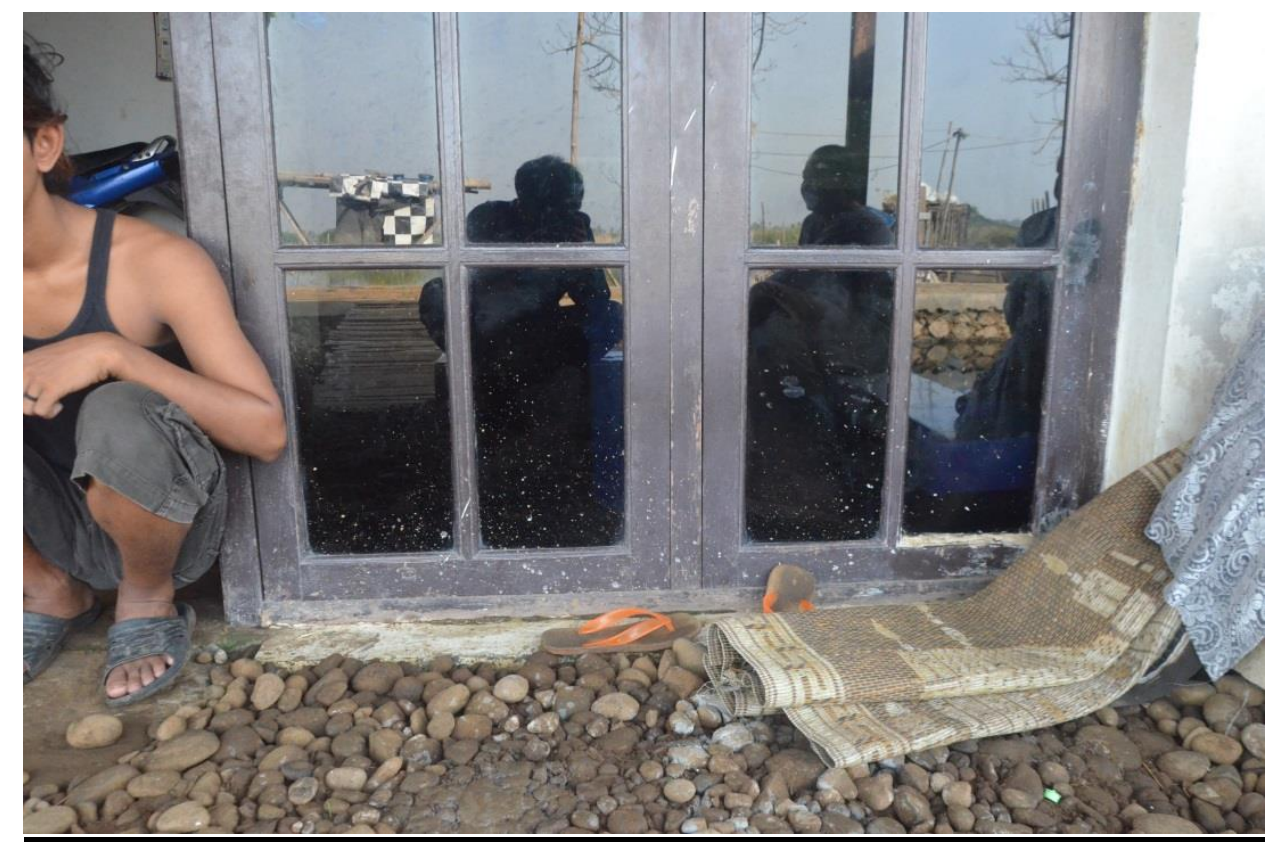

Gambar 3. Peninggian lantai rumah sampai setinggi jendela sebagai upaya adaptasi terhadap banjir rob di pesisir Kabupaten Pekalongan (Dokumentasi Pribadi, 17 Juni 2014) 


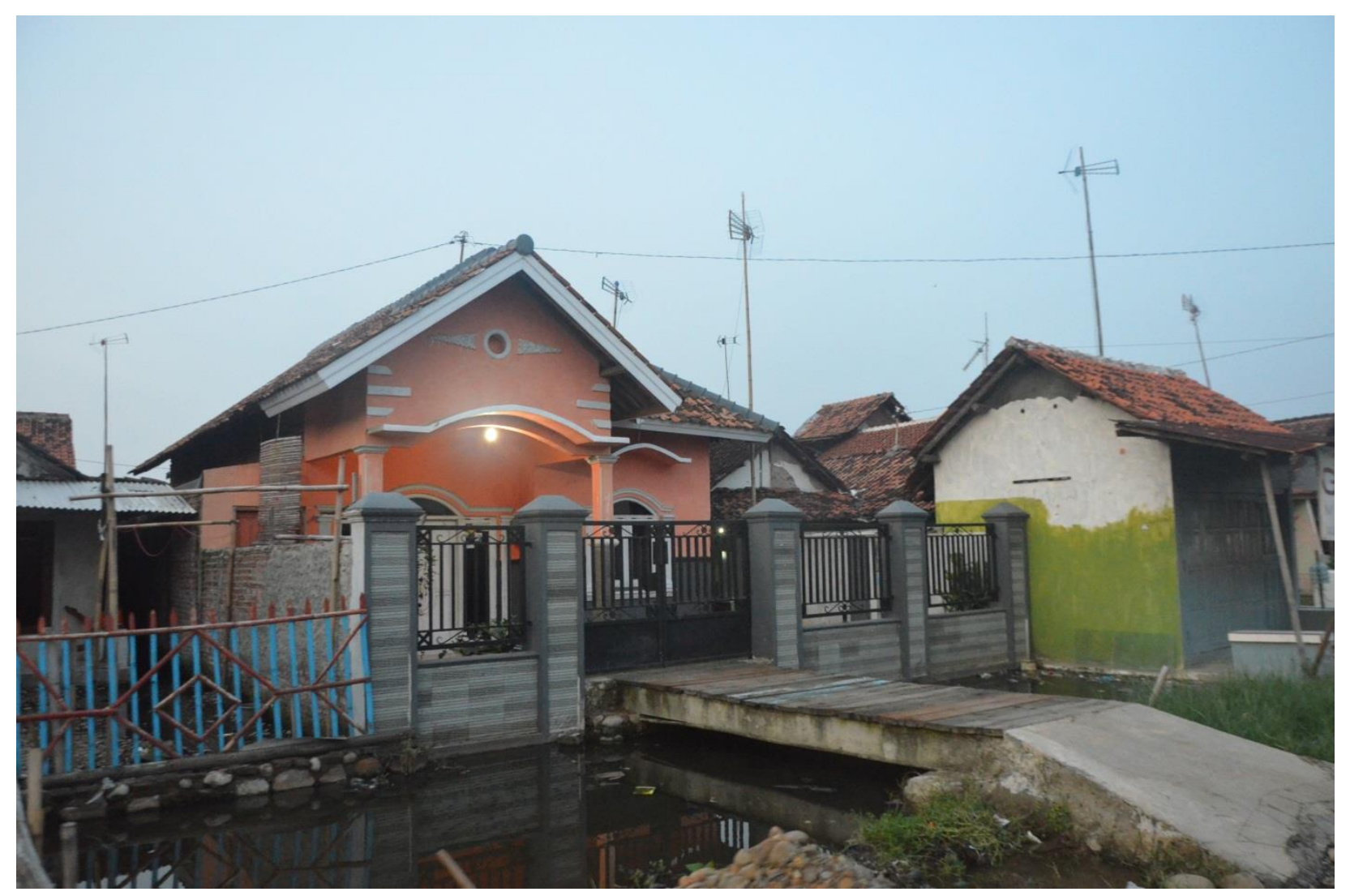

Gambar 3. Pembuatan tanggul yang tinggi di depan rumah sebagai bagian dari adaptasi terhadap banjir rob di Kabupaten pekalongan (Dokumentasi Pribadi, 17 Juni 2014)

\section{Dampak Terhadap Insfrastruktur dan Fasilitas Umum}

Banjir rob yang telah terjadi di Kabupaten Pekalongan telah menyebabkan terjadinya kerusakan infrastruktur dan fasilitas umum. Beberapa kerusakan infrastruktur dan fasilitas umum yang terjadi antara lain adalah kerusakan jalan raya, kerusakan fasilitas pendidikan seperti bangnunan sekolah serta kerusakan tempat ibadah, Beberapa hal yang telah dilakukan sebagai upaya adaptasi terhadap banjir rob adalah menguruk jalan sebagai upaya untuk menambah tinggi jalan (Gambar 5.) meninggikan lantai bangunan sekolah atau tempat ibadah (Gambar 6.), membuat tanggul di depan lokasi berdirinya fasilitas umum.

\section{Dampak Terhadap Sanitasi dan Penyediaan Air Bersih}

Keberadaan air yang berasal dari genangan banjir rob menyebabkan kondisi lingkungan di sekitar permukiman menjadi kurang baik. Salah satunya nampak dari kondisi sanitasi. Banjir rob telah mengakibatkan air limbah yang berasal dari sanitasi tidak dapat dibuang sehingga toilet dan kamar mandi tidak dapat difungsikan. Hal ini menyebabkan banyak masyarakat yang kemudian membangunan fasilitas Mandi Cuci Kakus (MCK) di atas sungai yang terpisah tanggul dengan permukiman warga (Gambar 7.). 


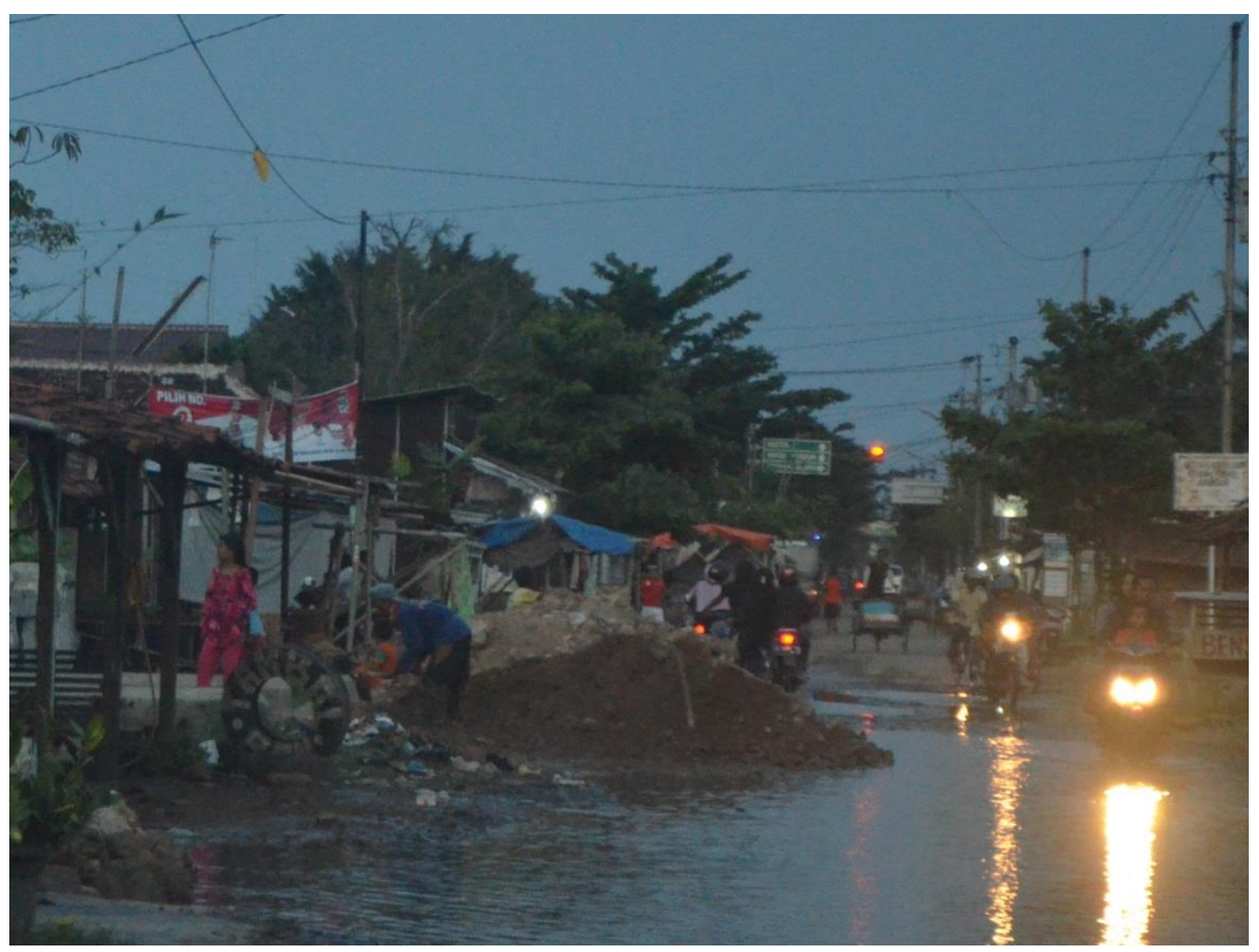

Gambar 5. Peninggian Jalan sebagai bagian dari adaptasi terhadap banjir rob di Kabupaten Pekalongan (Dokumentasi Pribadi, 17 Juni 2014)

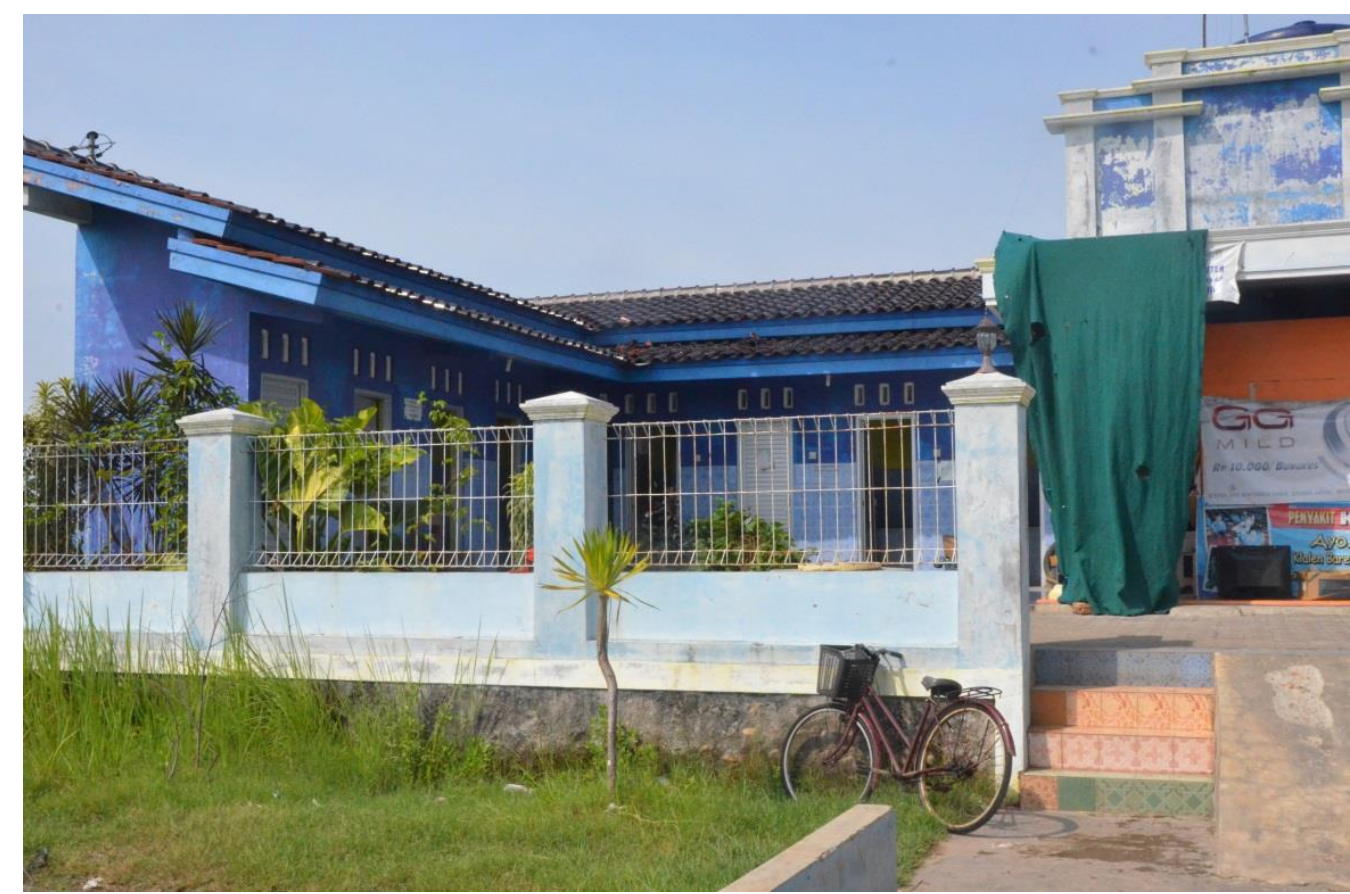

Gambar 6. Peninggian lantai bangunan sebuah sekolah sebagai bagian dari adaptasi terhadap banjir rob di Kabupaten Pekalongan (Dokumentasi Pribadi, 17 Juni 2014) 


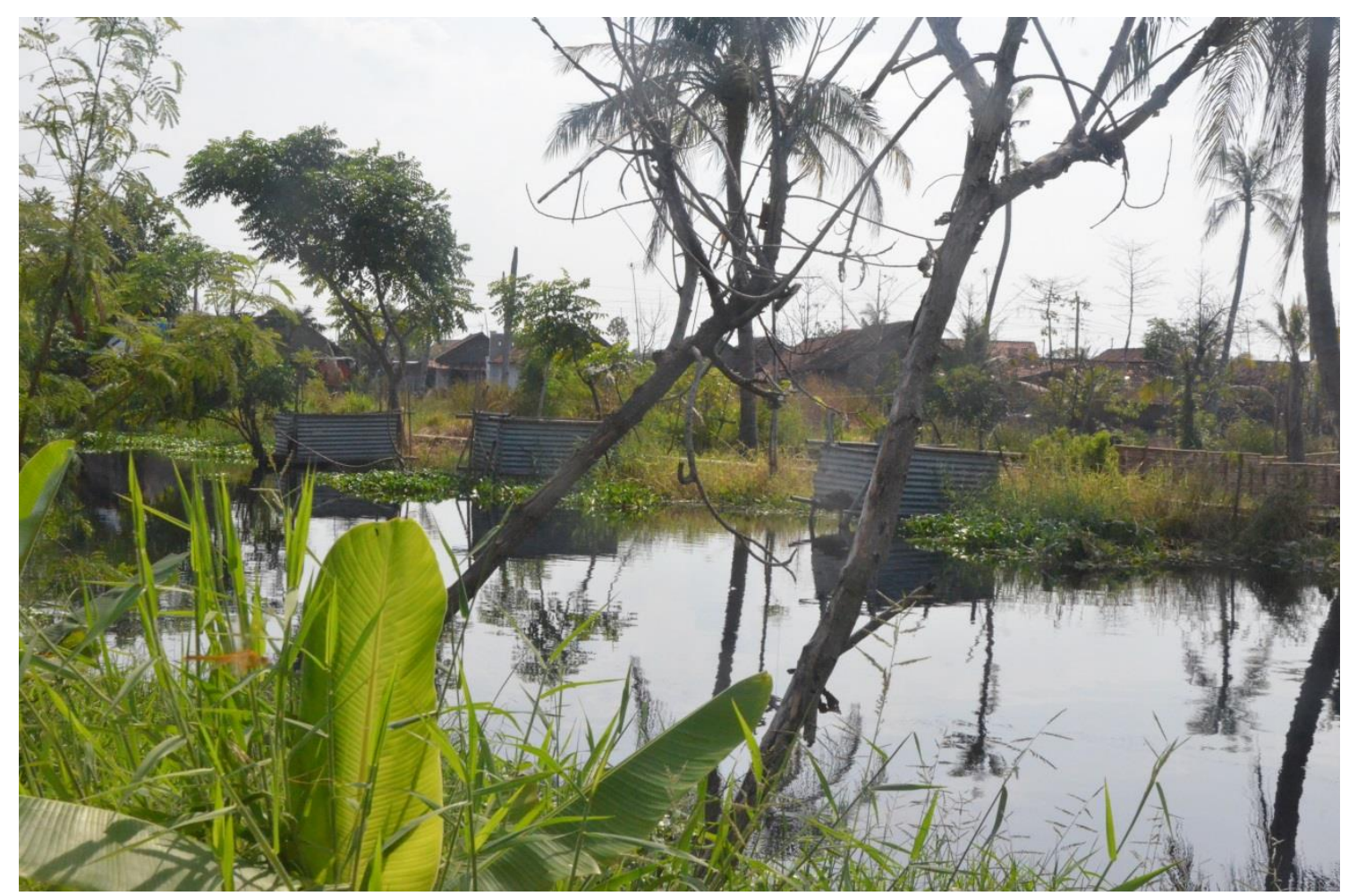

Gambar 7. Fasilitas MCK yang dibangun di atas sungai di Kabupaten Pekalongan

(Dokumentasi Pribadi, 19 Juni 2014)

\section{Dampak Terhadap Lahan Persawahan, Tegalan, Pekarangan dan Tambak}

Banjir rob di Kabupaten Pekalongan telah menyebabkan terjadinya kerusakan lahan persawahan, tegalan, pekarangan dan tambak. Banjir rob telah menyebabkan lahan persawahan tergenang air dengan salitas yang tinggi sehingga tanaman padi mengalami kerusakan dan mati (Gambar 8.). Banjir rob menyebabkan tanaman di lahan pekarangan mati dan lahan pekarangan tidak dapat digunakan untuk menanam tanaman yang bermanfaat bagi kehidupan karena kondisinya selalu tergenang air asin (Gambar 9.). Selain itu, banjir rob yang terjadi pada saat pasang yang tinggi menyebabkan kerusakan lahan tambak (Gambar 10.) dan banyak ikan yang lepas karena banjir menyebabkan air di dalam tambak meluap. Beberapa upaya yang telah dilakukan untuk beradaptasi dengan kondisi lingkungan yang dipengaruhi banjir rob adalah dengan memilih bibit padi yang dapat beradaptasi dengan kondisi salinitas yang tinggi, meninggikan tanggul pada persawahan dan tambak, serta memasang jaring pada tepian tampak sehingga ikan tidak hilang ketika terjadi banjir yang melebihi ketinggian tanggul tambak. 


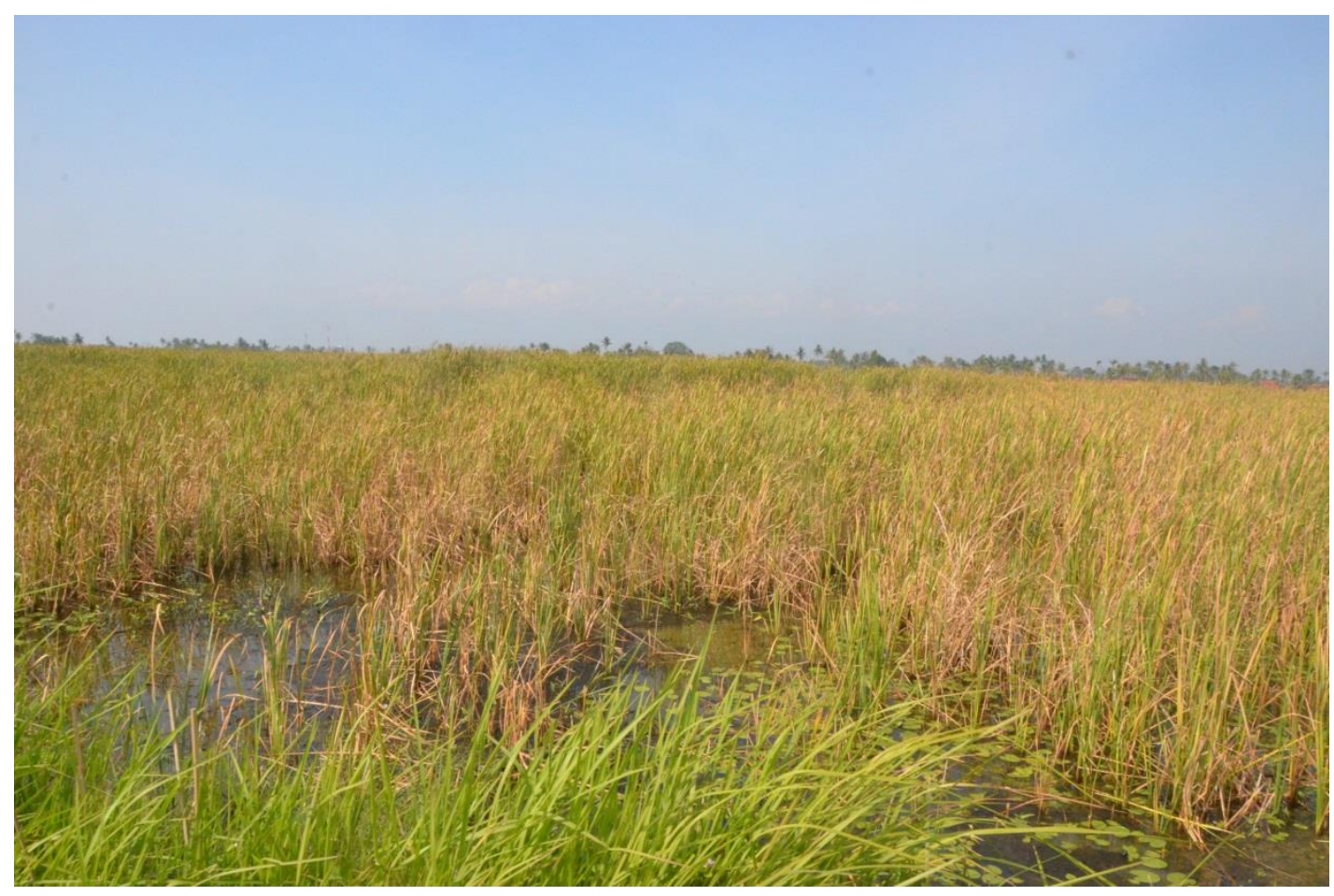

Gambar 8. Keusakan tanaman padi sawah akibat banjir rob di Kabupaten Pekalongan (Dokumentasi Pribadi, 18 Juni 2014)

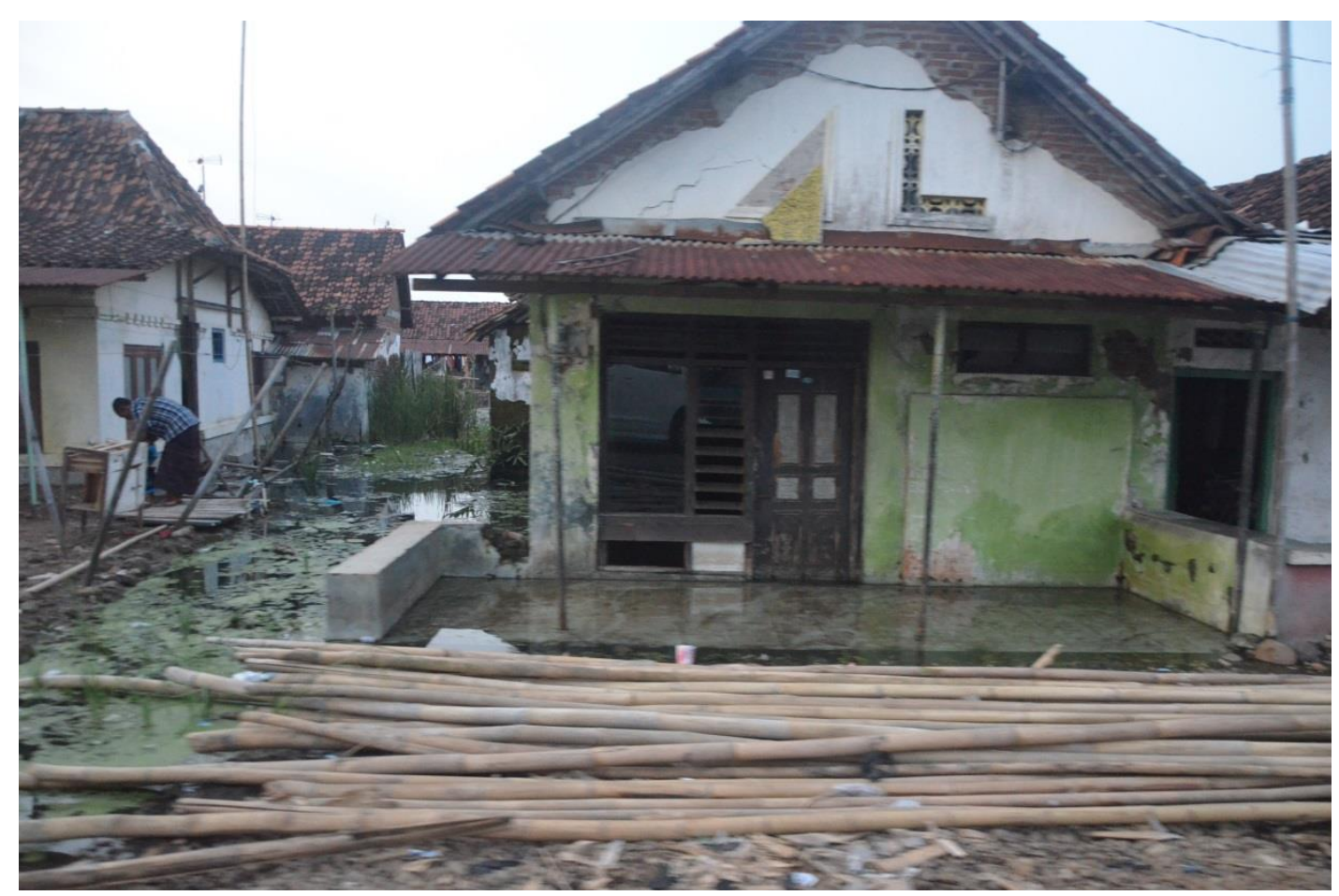

Gambar 9. Kondisi pekarangan yang tidak dapat dimanfaatkan untuk menanam tanaman akibat tergenang air dengan salinitas tinggi di Kabupaten Pekalongan

(Dokumentasi Pribadi, 19 Juni 2014) 


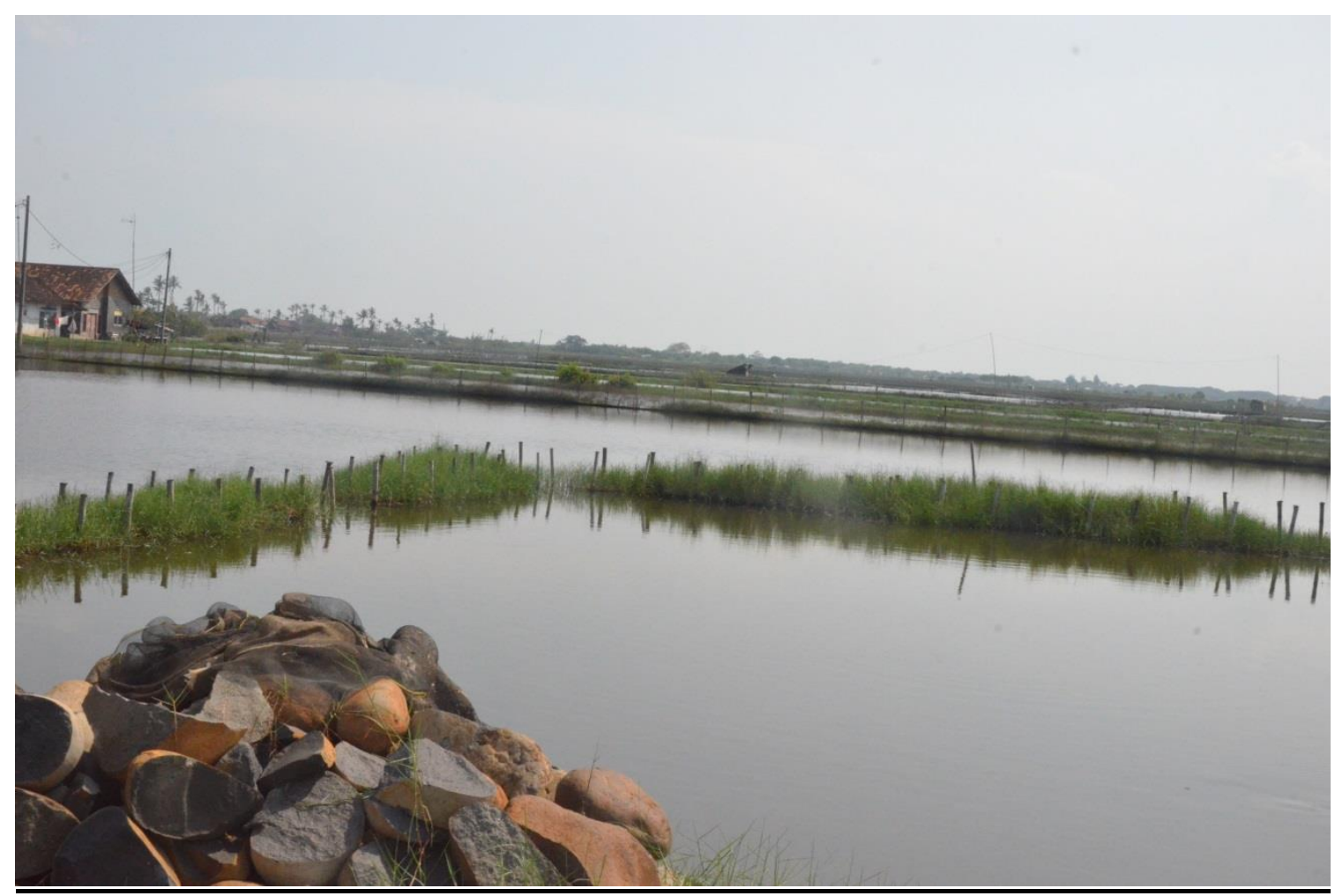

Gambar 10. Lahan tambak yang rusak di Kabupaten Pekalongan

(Dokumentasi Pribadi, 19 Juni 2014)

\section{Kesimpulan}

Berdasarkan hasil kajian yang telah dilakukan, maka disimpulkan beberapa hal sebagai berukut:

1. Banjir rob di Kabupaten Pekalongan telah menyebabkan terjadinya kerusakan rumah, infrastruktur jalan, fasilitas umum seperti sekolah dan layanan kesehatan, sanitasi, lahan pekarangan, tegalan, persawahan dan lahan tambak;

2. Pola adaptasi masyarakat terhadap banjir rob diantaranya adalah meninggikan bagian depan rumah, membuat rumah tingkat, melakukan migrasi, meninggikan jalan, membuat tanggul selokan, membuat sanitasi di atas sungai, meninggikan bedengan tambak, meninggikan batas tambak dengan jaring dan memilih bibit tanaman padi yang tahan terhadap salinitas yang tinggi.

\section{Daftar Pustaka}

Cabanes, C., Cazenave, A; dan C Le Provost, 2001. Sea level Rise During Past 40 Years Determined From Satellite and in Situ Observation Science, 294.

Cazenave, A., dan Nerem, R.S.. 2004. Present-Day Sea Level Change : Observation and Cause. Review of Geophysics, No. 42, RG3001. 
Mardiatno, D.; Marfai, M.A.; dan Sartohadi, J. 2009. Multi-risks of Disasters in Cilacap City, Indonesia. Proceeding International Coastal Conference, Nagoya Japan. 23-25 February 2009. Hal: 6-14.

Marfai, M.A. dan King, L. 2008a. Tidal Inundation Mapping Under Enhanced Land Subsidence in Semarang, Central Java Indonesia. Natural Hazards, Vol. 44. Hal: 93109.

Marfai, M.A. dan King, L. 2008b. Potential Vulnerability Implications of Coastal Inundation Due to Sea Level Rise for The Coastal Zone of Semarang City, Indonesia. Environmental Geology, Vol. 54. Hal:1235-1245.

Marfai, M.A. dan King, L. 2008c. Coastal Flood Management in Semarang, Indonesia. Environmental Geology, Vol. 55. Hal: 1507-1518.

Marfai, M.A.; Yulianto, F.; Hizabron, D.R.; Ward, P. dan Aerts. 2009. Preliminary Assessment and Modeling The Effects of climate change on Potential Coastal Flood Damage in Jakarta. Joint research report. Vree Univ Amsterdam dan Fakultas Geografi, Universitas Gadjah Mada.

Nicholls, R.J.; de la Vega-Leinert dan Anne. 2000. Overview of The SURVAS Projet, Makalah pada Proceeding of APN / SURVAS / LOICZ Joint Conference on Coastal Impacts of Climate Change and Adaptation in The Asia-Pacipic Region, Kobe Japan 14-16 Nopember 2000.

Sartohadi, J.; Marfai, M.A.; dan Mardiatno, D. 2009. Coastal Zone Management Due to Abrasion Along The Coastal Area of Tegal, Central Java Indonesia. Proceeding International Coastal Conference, Nagoya Japan. 23-25 February 2009. Hal: 37-44.

Sutrisno D.; Pariwono, J.; Rais, J. dan Kusumastanto, T. 2005. Dampak Kenaikan Muka Laut pada Pengelolaan Delta: Studi Kasus Penggunaan Lahan Tambak di Pulau Muaraulu Delta Mahakam. Jurnal IImiah Geomatika Vol.11(1). September 2005. 